\title{
HAJAMÄRKUSI KAUAOODATUD ETÜMOLOOGIATE PUHUL
}

\author{
MATI HINT, RAIMO ANTTILA
}

$\mathrm{E}$ esti etümoloogiasõnaraamatu ${ }^{1}$ (edaspidi ETS) tutvustuse esimene osa käsitleb sõnaartiklite ülesehitust ja esitustehnilisi küsimusi. Soome keelega ühiste tüvede puhul saab materjali võrrelda koguteosega „Suomen sanojen alkuperä" (SSA) ja soome keele varasemate etümoloogiasõnaraamatutega; see töö on eesti sõnaraamatu tegijatel kindlasti tehtud. Ülejäänud sõnavara etümoloogiate kogumisel ja süstematiseerimisel on sellises mahus sõnaraamat suurel määral teerajaja - tänuväärne ja samas tänamatu roll. Kes see ikka aru saab, kui riskantne on etümoloogia.

Esimene küsimus selle sõnaraamatu puhul on: kellele see on mõeldud, kes on adressaat? Keeleteadlastel võib sõnaraamatule olla pretensioone, laiatarbesõnaraamatuna aga temast praktilisele inimesele kasu ei ole. Kuid huvi sõnaraamatu vastu oli hämmastavalt suur, kiiresti tuli teha mitu kordustrükki. Järelikult oodati teda väga. Üks lünk eesti sõnaraamatute süsteemis on täidetud, tehtu täiendamine on juba kergem.

\section{Sõnaseletused}

Sõnaraamat tahab täita ka tänapäevase seletussõnaraamatu ülesandeid. See taotlus on enamasti ülearune ja kahjustab sõnaraamatu tõsiseltvõetavust. ETS ei võta arvesse, et sõna tänapäevane teaduslik mõistesisu ja etümoloogiliselt primaarne tähendus võivad olla teineteisest väga kaugel, argitähenduse ja entsüklopeedilise definitsiooni kokkusobitamine on raske.

Järgnevas pole ülepingutatud tähenduste näited tähestiku järjekorras, valikusse on püütud hõlmata erinevaid tähenduspiirkondi.

hing 'õhu kopsudesse tõmbamine ja sealt eemaldamine; kopsudest eemaldatav õhk; elu; eluvaim; elusolend, hrl inimene'. Kui minna väheke edasi, siis peaks kirjeldama ka seda, kuidas see õhu tõmbamine ja eemaldamine käib, mängu tuleks diafragma ja tõmbamise-eemaldamise sagedus. See viimane märkus ei olegi irooniline, sest ka hingama ja hingeldama oleks väärinud äratrükkimist, aga verbe pole; köhimisega on vastupidi.

köhima 'hingamisteede limaskestade tundenärvide ärritusest tingitult järsult häälekalt ja reflektoorselt välja hingama'; köha märksõnana puudub. Niisugused vastuoksused (ja neid on palju) räägivad sellest, et märksõnade ja nendega seostatava sõnapere esitamine ei ole süsteemselt läbi mõeldud.

laine 'ruumis leviv energiat edasi kandev võnkumine'. Ja kõik. Olid ikka meie esivanematel seda sõna laenates põhjalikud teadmised tänapäeva füüsikateooriatest! Etümoloogia mõistesse kuulub siiski ka sõnade esialgse, pri-

${ }^{1}$ Eesti etümoloogiasõnaraamat. Koostanud ja toimetanud Iris Metsmägi (peatoimetaja), Meeli Sedrik, Sven-Erik Soosaar. Tallinn: Eesti Keele Sihtasutus, 2012. 792 lk. 
maarse tähenduse jälitamine; lainet ei ole kindlasti laenatud energiat edasi kandva võnkumise tähistamiseks.

rong 'raudteerööbastel liikuv vedurist ja vaguni(te)st koosnev mootorv elektrisõiduk reisijate v kauba veoks; üksteise järel asetsevate esemete v olendite rodu v kolonn'. Oleks piisanud näitesõnadest raudteerong, pulmarong (algsem kui eelmine), rongkäik; rongikäik ja raudteerong on Wiedemanni sõnaraamatuski olemas. Wiedemannis on teisigi, nüüdseks vananema hakanud sõnakasutusi (palverong, killarong), mis näitavad, et rööbastel liikuv värk on selle sõna tähenduses igal juhul sekundaarne (tänapäeval ei pea ei rööpad ega rong enam vastama ka ETS-i kirjeldusele). Üks algsemaid rongi-sõnu, mis pealegi tänapäevani kasutusel - pulmarong -, on ETS-ist hoopis välja jäänud. Sõna päritolust ei tea me ikka midagi.

maa 'Päikesest kauguselt kolmas Päikesesüsteemi planeet; maismaa, maismaa pind; ruumiline vahemaa; riik'. Kas esimesena toodud astronoomiline seletus on sõna etümoloogiline tähendus? Palju maisemad tähendused nagu 'muld' ja 'maakond' on jäetud kõrvale.

päike 'Galaktika täht, mille ümber tiirlevad Maa ja teised Päikesesüsteemi planeedid' - seletus on pärast Maaga tutvumist ootuspärane, aga see ei puutu kuigivõrd sõna etümoloogilisse tähendusse.

vanker 'sõiduvahend; teatud malend'. Aga miks mitte veovahend või sõjavanker? Ja oli ju veel hiljuti ka jõuvanker (Kraftwagen). ETS-is on vanker ka malend, aga et ka näiteks kuningas on malend või mängukaart, seda pole märgitud ja õige ongi. Mõistlik oleks ilmsed spetsiifilised sekundaar- ja slängitähendused välja jätta.

rist on liivi, vadja, isuri ja vepsa keeles ka kaardimängus mast, eesti keeles mitte (430); ristiinimene ja Christenmensch on ära toodud, ununenud on liivi rišting 'inimene'.

inimene 'mõtlemis- ning kõnevõimeline ühiskondlik olend (Homo sapiens)'. Tõesti rõõm kuulda.

käsi 'inimese v ahvi ülajäse tervikuna, õlast kuni sõrmeotsteni; ülajäse randmest sõrmeotsteni'.

suu 'seedekulgla osa huultest neeluni'. Mõne teise läänemeresoome keele puhul saab suu lisatähendused suue ja ava, mis tegelikult ei puudu ka eesti keeles, kohanimedeski on Jõesuu ja Lohusuu.

kõht 'rindkere ja vaagna vahel asetsev (loomadel alumine) kehaosa', lõunaeesti $k \tilde{t} t$ (mittelõunaeestlane võib seda lugeda ka $k \tilde{o} t^{\prime} t$ ).

mõtlema 'keeruka ajutegevuse abil asjade, nähtuste vm omadusi ja seoseid leidma, järeldusi ja otsustusi tegema; kavatsema; kujutlema'. Molekulaarset biokeemiat ja sünaptilisi seoseid pole sõnaseletusse siiski toodud.

Muidugi on ka igati mõistlikke sõnaseletusi: nt kõndima 'käima, astuma, sammuma' või loobuma 'end (vabatahtlikult) ilma jätma'.

Ekskrementide ja sugueluga seotud sõnade puhul on teaduslike sõnaraamatute praktika, et neid ei väldita. ETS-is on nii leebemad kui ka vängemad väginimisõnad enamikus sees, tegusõnu mitte, kuigi mõni selle valdkonna tegusõna on laialdase sugulaskeelte spektriga. (Huviline leiab need sõnad ja tuvastab ka puuduvad - kergesti.) Ülekandeliselt obstsöönseks muutunud sõnade puhul on panema udmurdi ja komi vastete puhul sugulise vahekorra tähendust märgitud, eesti märksõna puhul mitte; hõõruma puhul on see tähendus mitmes põhjapoolses läänemeresoome keeles tavaline, aga seda pole 
märgitud. Obstsöönsed tähendused pakuvad etümoloogilist huvi, kuna valdkonna tundlikkuse tõttu levivad selles tähenduspiirkonnas kiiresti ülekantud tähendused, mis võivad muutuda üheks põhitähenduseks - algne slängikasutus võib pretendeerida koguni kirjakeelsusele (näiteks kepp ja sellega seotud tegusõnad).

Ülekantud tähendused on huvitavad just siis, kui nad on levinud laiemalt, mitte ainult ühes keelemurdes. Lähedasteski sugulaskeeltes toimub see etteaimamatu protsess iga sõna puhul eraldi, seetõttu ei ole ülekantud tähenduste esitamine sõnaseletustes põhimõtteliselt halb, halb on, kui primaarseid ja sekundaarseid tähendusi ei eristata: elama 'eksisteerima, olemas olema; asuma; säilima, püsima' tähenduskirje kaks viimast liiget osutavad, kuidas ülekandelised tähendused on võrdsustatud primaarsetega (nt Kadunuke elab edasi meie südames).

Eesti ja soome keele võrdlustes on niisugused tähendusnihked tuntud, aga nad ei puudu ka põhjaeesti ja lõunaeesti vahel (vrd lõunaeesti nilbe 'libe', verrev 'punane', laitskene 'tütarlaps', rott 'hiir'). Liivi je'llõ 'elada' üheks põhitähenduseks kujunes 'töötada', jelu aga on elumaja (ka Sõrves ja mujalgi Saaremaal, liivilaenuline tähendus muidugi).

\section{Tuletised, etümoloogilised kaugseosed ja lõunaeesti}

mõtisklema eeskujuks on soome mietiskellä. Soome keele puhul on selge, et mietiskellä on miettiä tuletis. Eesti keeles on mõtlema ja mõtisklema seos tegelikult sama, aga see on tagantjärele tekkinud tuletusseos, mis pole etümoloogiline. Kui soome miettiä tõenäoliseks allikaks on vene smétit' ning see kuulub ka mietiskellä etümoloogiasse, kas on siis eesti keele puhul õige märkida vene lätet ainult mõtisklema puhul ja jätta see välja mõtlema etümoloogiast (ETS: 293; vrd SSA II: 166 jj)?

On otse paratamatu, et laenatud sõna hakkab sihtkeeles kuuluma uutesse seostesse. Näiteks number : nummerdama, klamber : klammerdama näitavad süsteemipärast laadivaheldust tuletussüsteemis ja nii seda tulebki käsitleda, kuigi number ja nummerdama pole keelde tulnud tuletusseoses olevate sõnade laadivaheldussuhtega (vt ka ETS: 321). Sama on mõtlema ja mõtisklema tuletussuhtega, mida eesti keele pinnal pole otseselt olnud.

Tuletiste esitamisel on ETS-is raske leida läbinähtavat valikuprintsiipi. Verbi ja nimisõna paaride jälgimisel on pilt selline: elama on sees, aga elu on jäänud välja, voolama on sees, aga voolu pole, tehe (< tegema) on sees, aga nähe puudub (mõlemad tuletised on ühtmoodi hilised).

Küsimus on ka, kui sügavale on etümoloogilises tuletusseoses kokkukuuluvate sõnade ühendamisel mõistlik minna, kui tähendused on juba kaugele lahknenud. Näiteks kaas, katma, katus kuuluvad etümoloogiliselt kokku, tänapäeva keele seisukohalt on nende tähendused iseseisvunud. ETS esitab kaas : kaane : kaant ja katma koos, nii et katma soome jt sugulaskeelte sõnakujud ja ülekandelisedki tähendused (kuni kaardimänguni välja!) on kaas : kaane all, mitte katma all, kuigi verbil on oma viidemärksõna, mis juhib tagasi kaane juurde. Samamoodi teeb soome SSA II (301, 329), aga seal mahuvad sõnaperekäsitlusse ka katus, kate jts; ETS-is katus ja kate puuduvad, mistõttu etümoloogilised seosed jäävad hajusamaks. 
Eberhard Winkleri ja Karl Pajusalu salatsiliivi sõnaraamatus on ühte sõnapesasse kokku pandud isegi keel ja keelama (Winkler, Pajusalu 2009: 81 jj). ETS nii kaugele ei lähe, keel ja keelama on järjestikused, aga iseseisvad märksõnad, mis tundubki kõige normaalsem (ka SSA I on valinud nad iseseisvateks märksõnadeks koos viitega tuletusseosele). ETS viitab keele all märksõnadele keelama ja kõõlus; viimase puhul „on arvatud, et tuletis tüvest keel". Tahaks teada, kes ja kus.

Intrigeeriv on sõnade riik ja rikas etümoloogiline vahekord. SSA III esitab nad lahus, aga viidetega nende seostatusele. Sama teeb ETS (427, 429). Kui sõnaartiklid oleksid viitekirjandusega täiendatud, siis oleksime neis artiklites loodetavasti leidnud osundused näiteks Heinrich Stahlile (Stahl [1637] 1974: 100), Georg Müllerile (Habicht jt 2000: 294, 296-297) ja Wastsele Testamendile 1686 (viimases näeb rikkust nii Meie Isa palves kui ka teistes taevariigi või kuningriigi tähendamissõnades koguni 1850. aastani välja): Sinno Rikkus tulgo ja Sest sin̄o perrält om se Rikkus nink se Wäggi nink se Auwustus... (WT [1686] 2001: Matteuse 6: 10,13). Kuidas riik ja rikkus on Uue Testamendi põhjaeestikeelsetes tõlkekatsetes $1680-1705$ vaheldunud, seegi on tänapäevaste publikatsioonide põhjal jälgitav (Ross 2007: 498-499). Põhjaeestikeelses piiblis 1739 on nendes kohtades juba riik.

Sissejuhatuses käsitletakse lõunaeestit põhjaeesti enam-vähem võrdväärse paralleelina, sõnaraamatus kahjuks mitte, nii et me saame enamiku märksõnade puhul küll teada, mis kujul ja missuguste tähendustega esineb sama sõna sugulaskeeltes, aga seda, kuidas see on teises eesti keeles, märgitakse üsna harva ja sedagi tõsiste väljalugemisprobleemidega. Ersa ja mokša seevastu on järjekindlalt esindatud.

Sissejuhatuses tehakse põhjaeesti keeles vahet näiteks kirderannikumurde ja südaeesti keele vahel, lõunaeesti on kõik üks: seda esindab kord võru-, kord tartukeelne sõnakuju. On siiski vahe näiteks Võru murde kö̈̈ds (ETS-is) või Tartu murde keids vahel, mõlemast variandist saab tõmmata häälikumuutuslikke seoseid teiste läänemeresoome variantideni, mõlemad oleksid omal kohal. Laiatarbesõnaraamatus ei ole ühe variandi kokkuhoidmine suur patt, aga kui asutakse ette valmistama sõnaraamatu teaduslikumat väljaannet, siis ootaks suuremat täpsust.

Mõnikord seostuks lõunaeesti sõnakuju etümoloogiliste paralleelidega paremini kui kirjakeele sõna: kuusk 'igihaljas tiheda koonusja võraga okaspuu (Picea)'; sõna on sugulaskeeltes ilma $k$ laadivahelduseta, aga lõunaeesti kuus : kuuse : kuust ETS-is puudub. Laensõnadest annavad näiteks lõunaeesti pürst ja undruk (mõlemad ETS-is sees), erinevalt kirjakeelsetest sõnadest hari ja seelik, otsejoones välja oma päritolu mõnest saksa keele variandist.

Kunsttüvede ja kunstsõnade välmimine (seegi kunsttüvi) on moodsa eesti keele sõnavara täiendamisel suurema tähtsusega kui enamikus meile tuntud keeltes. Paljud eesti keeleharrastajad peavad seda meetodit eesti keeleteaduse Nokiaks ja sõnavaratöö peamiseks mõtteks. ETS heidab selliselt tekkinud sõnavara kokku ühte ebamäärasesse patta märgenditega tehistüvi või keeleuuenduse ajal loodud tehistüvi või tehistüvi 1920. aastatest vms. Kui tüveloomingu autorsus on teada, miks siis jätta märgendamata Kreutzwaldi tuletised, Grenzsteini kunstsõnad ja tuletised, Aaviku tehistüved, Manivalde Lubi sõnad jne. Alo Rauna „Eesti keele etümoloogiline teatmik” (1982) teeb nii ja kasutaja saab olulise lisaviite. 


\section{Sõnaartikli esitamistehnika ja kirjaviis}

ETS-i sõnaartikli viited sugulaskeeltele on üles ehitatud kõige vähem mõttevaeva nõudval moel:

vadja susi 'hunt'

soome susi 'hunt'

isuri susi 'hunt'

karjala susi 'hunt'

või

vadja ilves 'ilves'

soome ilves 'ilves'

isuri ilves 'ilves'

Selliseid näiteid on palju-palju.

Miks mitte näiteks vadja, soome, isuri, karjala susi 'hunt'; kandma läänemeresoome keelte tähenduskirjetes kordub '(üles tõstetuna) edasi toimetama' kaheksa korda!

Kahjuks on põhimõtteks võetud, et sõnaraamatus kirjutatakse märksõnad ja nende põhivormid kõige tavalisemas ortograafias, isegi õigekeelsussõnaraamatu täpsustavaid lisamärke III-välteliste silpide ja palatalisatsiooni märkimiseks pole vajalikuks peetud. See ei lähe kuidagi.

Sama põhimõtet kasutatakse murdenäidete puhul: need kirjutatakse kirjakeelepäraselt ja hääldust täpsustavaid lisamärke kasutamata (vt ka joonealust viidet sissejuhatuses lk 21). Sugulaskeelte sõnanäidetes on vähemalt palatalisatsiooni märgitud ja kaugemate etümoloogiate esitamisel on kasutatud ka täpsustavaid diakriitikuid.

Pealiskaudse ortograafia kasutamisest tuleneb hulgaliselt väljalugemisraskusi:

kaks, lõunaeesti kats; ei ole nii, on kas kat's või kaits;

laps, lõunaeesti lats: ei ole nii, on kas lat's või laits.

kutsu : kutsu : kutsut 'LASTEK koer' - sõnaraamatu välismaalasest kasutaja ei või kuidagi teada, kuidas seda sõna lugeda: võimalikud on väldet ja palataliseeritust-palataliseerimatust kombineerides neli erinevat hääldust. Selle arvamuskirjutise kaasautor loeb seda III vältes ja palataliseerimatuna. Sama lugu on notsuga; ka musu, nosu, mats, matt, mutt, puss jt vajavad palatalisatsioonimärki. Palatalisatsioonimärgita ortograafia tõttu ei saa olla kindel ei palataliseeritud ega ka palataliseerimata häälduses.

Ka tüvevokaali märkimata jätmine on halb otsus: selg : selja on ETS-i järgi lounaeesti sälg, aga see pole sälg : sälu, vaid säl'g : sällä või sälä̈.

Lõunaeesti seisukohalt on olulised afrikaadilised sõnad, lõunaeesti keelelise ürgidentiteedi üks tunnusjooni: katki - ETS-is puudub kat'ski; part - ETS-is puudub parts; lõunaeesti sõnakuju on suure sagedusega perekonnanimi ja juba seetõttu oleks selle äratrükkimine põhjendatud.

Mõnes sõnas on lõunaeesti afrikaadil selged vasted sugulaskeeltes: selline on näiteks küüs : küüne : küünt 'inimese sõrme v varba lõpplüli selgmist osa kattev plaatjas sarvmoodustis'; siin on lõunaeesti vaste ETS-is kü̈̈dś; see on üks haruldane kord, kus eesti sõnavormis märgitakse palatalisatsiooni, sest märkimisviis järgib Sulev Iva „Võru-eesti sõnaraamatut” (2002), aga too sõnaraamat on orienteeritud võru kirjakeele ortograafia kindlustamisele, mitte niivõrd häälduse edasiandmisele. Teised allikad kirjutavad ikkagi küids või 
küüd's; palatalisatsioonimärgi asukohast olenemata on õige tõlgendus, et Võru murdes (võru keeles) on palataliseeritud afrikaat.

suskama 'torkama, pistma' lõunaeesti vaste tsuskma ei ole päris õige, õige oleks tsuskama; tsuskma on frekventatiiv 'torkima'; songima puhul seevastu on lõunaeesti tsongma õige (kuid häirib palatalisatsiooni märkimata jätmine), sest see on tõesti frekventatiiv. Vahe on ka selles, et tsuskama on tugevneva ja tsongma (tsoy'gma) nõrgeneva astmevaheldusega verbitüüp.

Algallikatega võrdlemisel leiab väikesi küsitavusi, aga nendes orienteerumiseks pole selle arvamuse kirjutaja pädev. Näiteks paljuvaieldud taldriku allikatest on Robert Hinderlingil (Hinderling 1981: 166) ka umlaudiga keskalamsaksa vorm tallör(e)ken (ETS-is alamsaksa talloreken); lõunaeesti III-välteline ja palataliseeritud 'tal'drik seostuks paremini algallika eesvokaaliga $\ddot{o}$.

nemad puhul on liivi vaste millegipärast antud omastava kujul (nänt), kuigi Kettuneni sõnaraamatus (mis eessõna järgi on Kuramaa liivi vastete allikaks) ne ei puudu (Kettunen 1938: 243).

Tulevikku väljendav leema ei ole eesti keeles kasutusel olev verb, nagu tekstist võib välja lugeda. See ei tähenda, et sõna peaks etümoloogilisest sõnaraamatust välja jääma, aga tal peaks olema vastav märge. Ka uudissõnade ja slängisõnade puhul ootaks vastavat märkust (nt taidlema, poppi tegema).

Sõnamuutmise esitamisel ootaks, et etümoloogilisest sõnaraamatust selguks ka sõna vanem (nt astmevahelduslik) muutmisviis, vähemalt siis, kui see on normikohane praegugi; sulgema, hälbima, pürgima, sattuma ja lõppema puhul see on nii, aga näiteks küündima : küündida : küündin on ETS-is ainult astmevahelduseta.

ETS-i kommentaaride stiil on tihti jutustav, kirje muutub väikeseks huvitavaks lugemispalaks (nt tala, seatina, tarduma).

Küsimus on ka, kui kaugele minna indoeuroopa laenude etümoloogiatega. Mõtlemisainet ja eeskujusid selleks annab ETS-i tutvustuse alljärgnev Raimo Anttila kirjutatud osa.

\section{Indoeuroopa etümoloogiad}

Eesti keelt on ümbritsenud mitmed slaavi ning balti keeled ja paljud germaani keelevariandid. Jääb mulje, et kõige rohkem on mööda vaadatud balti keeltest, omamoodi lähimaist naabreist.

Sõna vähk on peetud õigustatult balti laenuks (vrd leedu véžys), aga on jäetud osutamata, et sellega kokku kuulub viima (tegelikult indoeuroopa tüvest *weǵh-, mitte *wegh- nagu sõnaraamatus). Samuti on soome keelest eesti keelde laenatud vihjama pärit alggermaani tüvest *wisja-, ehkki parim võimalus seda tõlgendada oleks balti allika põhjal (nagu soome keeleski).

Märksõnade laba, labu, lappama, lape, lapik vahel on rohkesti ristviiteid. Kõiki neid on iseloomustatud lihtsalt läänemeresoome sõnadena. Ainult labidas on esitatud balti laenuna, nagu on kombeks olnud, vrd leedu lapas, lapa 'leht, palakas, laba, plaat' (edasi ka lopa 'käpp, küünis, jalg / käsi' nagu sõnas labakäsi). Sõnad labastada, lapata jne võib kõrvale jätta, sest neid pole käsitletud.

Rohkete ristviidetega sõnapere moodustavad kola, kolama, koli(ma), kolu; kilama, kille jt, lisaks veel kõla, kõlisema - kõiki neid on hinnatud 
onomatopoeetiliseks või deskriptiivseks. Üksnes sõna kild on peetud balti laenuks ja kõld on küsimärgiliselt ühendatud soome sõnadega kelsi/kelle. Aga need kõik on balti laenud, mille lähtekohaks on verb skilti ( skala/skaldas) 'lõhustama', kaasa arvatud sõna kolle, milles võib näha Eesti tüüpilisi lõhenenud kive. Kogu see rida on eesti keeles sünnitanud suure hulga onomatopoeetilisi-deskriptiivseid üksusi, kuid nende pidepunktiks on laenuseos.

Uurali tüve õu puhul on mainitud ka alamsaksa laenu võimalust samast allikast mis sõnal hoov. Pigem on see seotud verbiga avama. Ablaudisarnane vokaalivaheldus $a \sim o / \tilde{o}$ on küll harv, aga seda tuleb ette (palama/põlema, soome palaa/polttaa). Märgitagu siin ka sõna oja, mis ETS-i järgi võib olla „tuletis vanast tüvest, mis on ka sõnas voog”. Vaevalt küll, pigem kuulub see kokku verbiga ajama; tegemist on veevoolunõvaga, nagu seda on ladina agmen. Verb ajama on ühendatud algindoeuroopa tüvega $a g$ - küsimärgiliselt, sest häälikuline vastavus olevat kaheldav. See on standardväide, milleks kõnealusel juhul pole mingit põhjust. Oletus, et äkki kuulub kokku sõnaga äge, võib ju mingis maailmas võimalik olla, kuid rootsi sõnaga äcka '*ajamine, aju' on seos otsesem, vrd soome yhtäkkiä (partitiiv) '*ühtaju' > 'järsku' (vrd ka genitiivne yhen äkin).

Sõna suhe on laenatud soome keelest ja soome suhde võib ETS-i järgi olla balti laen. Jah, päris kindlasti. Et sageli esitatakse ka murde- ja vananenud keelendeid, oleks tulnud seda teha siingi, et käsitlust eesti ainesega toetada. Miks mitte mainida Wiedemanni suda 'ganz, sehr', suda kõik 'allzumal' (Wiedemann [1893] 1973: 1082) või Gösekeni keick suhda 'allesambt; kõik koos, kõik kokku' (Göseken [1660] 1977: 104)? Vähemalt ühe sellise näite võinuks lisada. Tegemist on klassikalise murdegeograafia juhtumiga, kus keeleala keskmes toimub uuendus ja äärealal jäävad vanad vormid püsima. Eripärane on siin see, et keskmesse tehakse seejärel põhja suunast laen.

Raamat kubiseb ristviidetest, aga ikkagi jääb neid sageli selgelt vajaka. Sõna ori on küsimärgiliselt ühendatud algindoiraani tüvega *arya- või algindoeuroopa tüvega *worǵo- 'töötegija'. On õigesti märgitud, et tähendust seletab aarialaste sattumine vangi seisundisse. Vastete hulgas on ka saami oarji 'lääs'. Rikkalikus saami materjalis on sõnal selline tähendus üksnes Kautokeinos, mujal on kõikjal 'lõuna' või 'edel' (vrd märksõnu edel ja lõuna, soome lounas 'edel'). Sageli tuuakse esile küll laiemad seosed, aga mitte siin, kus parim asjassepuutuv tüvi on algindoeuroopa $*_{r}$ - 'minema'. Aarialased olid esialgu rändrahvas, enne kui neist uuel asualal sai ülemkiht. Seega peaks ori olema seotud sõnadega era- ja ird 'millestki lahti tulnud osa või asi'. Sõna ird esitatakse kui laenu soome sõnast $i r t i$; artikli lõpus mainitakse balti laenu võimalust (vrd leedu infinitiivi irti). See oleks parim seletus.

Sõna hind „on peetud ka balti laenuks”. Balti vastena on trükitud leedu sõna imtas, mille tähendusteks on märgitud 'sada; väga palju, suur hulk'. Tegemist on ilmse trükiveaga: õige leedu sõna on šimtas, leedu partitsiip imtas tähendab 'võetud' ning see ei puutu hinna etümoloogiasse.

kesi : kee : kett, kest jt puhul sedastatakse üksnes vastastikust kokkukuuluvust ilma vähemagi vihjeta tegelikule veenvale etümoloogiale; tegu on laenuga germaani skin-sõnaperest (*skinda- < algindoeuroopa *skentó-).

kõne on märgistatud lihtsalt läänemeresoome tüveks, ehkki see on balti laen leedu verbiga ginti 'ajama' seotud sõnaperest - vrd juttu ajama (sellega kuulub soome kone 'masin' tõepoolest kokku). Veel üks pelga soome-ugri mär- 
gendi saanud keelend on sula, aga seegi on uurali keeltes pigem algindoeuroopa laen (vrd sanskriti surā 'õlletaoline jook'; näiteks läti keeles on rohkesti samatüvelisi sõnu); sulane lähtub olukorrast, kus „magus poiss”, peig- või väimees, töötab „orjana” äia majapidamises.

Sõna õhv balti etümoloogiat (vrd leedu ašva 'mära') on peetud tähenduse tõttu kaheldavaks. Aga samas vahekorras on ka leedu žirgas 'hobune' ja eesti härg. Niisugused tähendusnihked on koduloomade puhul tavalised kogu maailma keeltes.

saun kui ?alggermaani *stakka- on varasematest parem seletus, aga kust tuleb - $n$ ? Et saun kuuluks kokku sõnaga taak või pärineks alggermaani sõnast *sāpna- 'seebikoda', on mõistusevastane (tõendusmaterjali pole esitatud), ehkki siin on vähemasti - $n$ - olemas. Parim lahendus on hiljuti välja pakutud *stak$n a$ - (vrd inglise smoke-stack, mille tähendus on lähedane eesti sõnale kolle).

haar / haru on esitatud vastavalt läänemeresoome-saami ja läänemeresoome-mari tüvena, ehkki pigem on tegu balti laenuga (vrd leedu žara, žaras 'oks').

hobune, soome hepo: „On arvatud, et tüvi on germaani laen, kuid sobivat laenuallikat ei ole leitud." Tõepoolest, aga see näeb välja nagu algindoeuroopa * $h_{1}$ ek'wos (ladina equus; vrd ašva), kus on nagu keldi keeltes (epo-) või kreeka keeles (hippos) toimunud muutus $k w>p$, ehkki sõnaalguline ${ }^{*} h_{1}$ - peaks andma pigem $k$ - nagu sõnas kesa. See jääb problemaatiliseks. Samal moel osutavad sõna sõnn puhul niihästi tähendus kui ka vorm laenamisele, „kuid sobivat laenuallikat pole leitud". On küll, selleks on alggermaani *standan 'seisma'; siia kuulub ka sõnnik (neid ei ole seostatud); vrd soome tehdas, algselt 'latter lehmalaudas, mille hõivaja tootis sõnnikut'; vrd ka inglise doo 'lapse kaka', kaugemas plaanis sama mis do 'tege-'.

Südi artikkel soome ületab uusimat soome sõnaraamatut ja käsitab seda balti, või veel etem, algindoeuroopa laenuna sõnast 'maa', *dhǵhom- (ladina humanus). Lokaalkoloriidi huvides võinuks lisada Saaremaa lätikeelse nime Sāmu sala 'soomlaste saar'. Imelikul kombel puuduvad viited artiklite soome ja saam vahel.

Algindoiraani keelendist *pekwetom 'keedetu' võimalikult laenatud sõna pett pole seostatud sõnadega köök, kokk ja küps, ehkki viimane vihjab balti sõnale keptas. Kõik need sõnad lähtuvad algindoeuroopa tüvest *pekw_ 'küpsetama'; germaani päritolu sõnade aluseks on ladina coquere (toimunud on assimilatsioon ja dissimilatsioon, balti sõna puhul metatees). Indoiraani partitsiibi puhul on kummaline joon lahtine , aga ka käändelõpp *-m. Mujal on need tasandunud.

Sõna pada ühendamisel indoeuroopa tüvega *pédo- jääb vokaali pikkus ja kvaliteet üsna küsitavaks ning sõna nimi tavapärane ühendamine tüvega *nōmn on selgelt ekslik, ehkki kirjanduses on see tavaline (ladina sõnale nōmen on mõju avaldanud tüvi *gnō- 'teadma').

Indoeuroopa algkeele tüvede indeks (lk 750-751) koosneb peaaegu täielikult Jorma Koivulehto loomingust, nii nagu ka enamik eespool toodud täiendusi ja parandusi. Sõnaraamat ei nimeta etümoloogiate autoreid, ehkki teose algul (lk 34-37) on esitatud kasutatud kirjanduse loend. Sellest pole kuigi palju kasu. Meiegi oleme hoidunud nimedest, aga Koivulehto väärib esiletõstmist, sest ta on üksipäini viinud uurali etümoloogiauuringud uuele kursile. Nii näiteks on ta osutanud, et uurali keeled pakuvad larüngaalide, ${ }^{*} H$-de $\left({ }^{*} h_{1}\right.$, 
${ }^{*} h_{2},{ }^{*} h_{3}$ ) kohta paremat tõendusmaterjali kui hetiidi keel, millest (ning F. de Saussure'i jt töödest) kogu asi alguse sai. Neid pole raamatus selgitatud ega defineeritud. Larüngaalid on hüpoteetilised mõistatuslikud spirandid, mis andsid külgnevale *e-le oma värvingu, pikendasid eelnevat vokaali ja langesid siis välja. Läänemeresoome keeltes kajastuvad nad isegi klusiilidena: *dheh ${ }^{-}$ $>$ tege-, *h $h_{3}$ okw- ('silm') > koge-.

Keelte kaupa järjestatud sõnaindeksid on head, aga keelte endi loendit tuleb otsida sisukorrast (mida kohe ei märka).

Trükipinda pole kokku hoitud, näiteks keelenimed on lühendamata, materjal esitatakse sageli tulbas, mille ümber on rohkesti vaba ruumi. Esitus on selline, et kõigepealt tuuakse ära traditsiooniline arusaam, siis uurali materjal ja lõpuks uuemad käsitlused, mis moodustavad kategooria teisalt (enamasti parimad hinnangud). Kaugemad sugulased on sageli varustatud küsimärgiga, mis võib olla sobiv ettevaatlikkus. Suurem jagu teisalt-kraami tuleb Soomest.

Üldtendentsina puuduvad laensõnade puhul ristviited, aga onomatopoeetiliste ja deskriptiivsõnade puhul tuuakse neid rohkesti. Ja tõesti, selliste sõnade poolest on eesti keel rikas, ehkki etümoloogial on nendega vähe peale hakata.

Uurali materjali puhul on diakriitiliste märkidega oldud kokkuhoidlik, et mittespetsialistil lugemist hõlbustada, ent eesti sõnade palatalisatsiooni ja väldet (nt partitiivis, illatiivis) oleks tulnud siiski märkida.

Indoeuroopa diakriitiliste märkidega on asi üldiselt korras, kuid tüvelõpu sidekriipsu, poolvokaalide $(r \sim r, u \sim w, j \sim y \sim i$ ) ja aspiratsiooni $(C h \sim C h)$ tähistamisel tuleb ette ebajärjekindlust. Paneb ka imestama, miks kreeka $k h$ on translitereeritud ch-na.

\section{Kuidas edasi?}

Teadusliku etümoloogiasõnaraamatu standarditele ETS siiski päriselt ei vasta. ETS-is on kommentaari alguseks sageli „On arvatud, et... ”; teaduslikus sõnaraamatus on selle asemel allikaviide. Palju on sõnu, mille puhul kasutatakse standardvormelit „Häälikuliselt ajendatud tüvi...” või „Häälikuliselt ajendatud läänemeresoome tüvi”. Eks läänemeresoome keeled ole tuntud oma deskriptiivsõnade poolest ja sõnaraamat esitab neid heldelt, aga võib ka olla, et eesti keele etümoloogia ootab oma Jorma Koivulehtot.

Tehnilised või teadusliku maailmavaate edenemisest tulenevad seletused (nt tänapäevased teadmised universumist) pole etümoloogiasõnaraamatus vältimatult vajalikud, pigem vastupidi: kui sõna rong tuli kasutusse tänapäevases põhitähenduses, siis ei olnud sellel mingit pistmist elektriga; samuti ei pea lainet tänapäevalgi tavatähendustes seostatama füüsikateooriatega. Tähenduse seletamise kramp ei edenda filoloogilist selgust, kui seletuses kasutatud sõnad vajaksid ise rohkemgi seletamist (nt ETS-is tellingu seletusena tarind).

Sõnaraamatuga on ära tehtud väga suur töö, mille edasine parandamine ei peaks olema ülemäära raske: tuleks lihtsustada ülepingutatud tähendusseletusi ja raskesti defineeritavate põhimõistete puhul nendest loobuda, on vaja teha vahet primaarsete ja sekundaarsete (metafooriliste) tähenduste vahel, ökonomiseerida sugulaskeelte vastete esitamist, kindlasti tuleb märk- 
sõnad esitada nende väljalugemist võimaldaval viisil, seda ka lõunaeesti vastetes. Ootaks, et lõunaeesti keelt ei koheldaks vähem iseseisva keelena kui isuri keelt. Tuleks mõtelda sellelegi, kuidas vaieldavatesse etümoloogiatesse ökonoomselt lisada kirjandusviiteid. Tõenäoselt on ETS-i koostajad neid probleeme arutanud, aga valinud lahendused, mida ei tahaks pidada lõplikuks.

Sõnaraamat on välja antud Eesti Keele Instituudi uuemate sõnaraamatute õnnestunud üldkujunduses. See kaubamärk väärib registreerimist. Siiski on vormist tähtsam sisu: minimaalne nõue enam-vähem kõigi eesti keele sõnaraamatute märksõnadele on selgus tüvevokaali ja muutmisviisi osas ning ÕS-i lisamärkide kasutamine (palatalisatsioonimärk ja III-vältelise silbi graavisemärk `silbi ees; graavise asendamine viimastes ÕS-ides mitmetähendusliku punktiga oli asjatu traditsiooni hülgamine - graavisemärk III-vältelise silbi ees läheb tagasi Elmar Muugi VÕS-ini 1933. aastal). Kahjuks võtab maad vastupidine tendents: märksõnade tavaortograafiat kasutab ka Silvi Vare hiljuti ilmunud kaheköiteline suursõnaraamat „Eesti keele sõnapered” (Vare 2012). Tolleski sõnaraamatus põhjustab III välte ja palatalisatsiooni märkimisest loobumine küsimusi, millele vastamiseks tuleb pöörduda teiste sõnaraamatute, sealhulgas ÕS-i poole. On siis niisugust mitmeastmelist tööd vaja?

Selle ühiskirjutisega tähistavad autorid oma kõige paremas võimalikus mõttes 45 aastat kestnud kolleegisõprust. Raimo Anttila teksti on ingliskeelsest käsikirjast tõlkinud Udo Uibo.

\section{Kirjandus}

G ö s e k e n, Heinrich [1660] 1977. Manuductio ad Linguam Oesthonicum. Anführung zur Öhstnischen Sprache. Kommenteerinud ja toimetanud H. Haarmann. Hamburg: Helmut Buske Verlag.

H a b i c h t, Külli, Ki n g i s e p p, Valve-Liivi, P i r s o, Urve, P rill o p, Külli 2000. Georg Mülleri jutluste sõnastik. (Tartu Ülikooli eesti keele õppetooli toimetised 12.) Tartu: Tartu Ülikool.

Hinderling, Robert 1981. Die deutsch-estnischen Lehnwortbeziehungen im Rahmen einer europäischen Lehnwortgeographie. Wiesbaden: Otto Harrassowitz.

I v a, Sulev 2002. Võru-eesti sõnaraamat. (Võru Instituudi toimetised 12.) TartuVõru: Võro Instituut.

Kettu ne n, Lauri 1938. Liwisches Wörterbuch mit grammatischer Einleitung. Helsinki: Suomalais-ugrilainen seura.

R a u n, Alo 1982. Eesti keele etümoloogiline teatmik. Rooma-Toronto: Maarjamaa. R o s s 2007 = Põhjaeestikeelsed Uue Testamendi tõlked 1680-1705: Luuka evangeelium; Apostlite teod. Koostanud Kristiina Ross. Tallinn: Eesti Keele Sihtasutus.

St a h 1, Heinrich [1637] 1974. Anführung zu der Esthnischen Sprach.... Rooma: Maarjamaa. [Faksiimile.]

SSA = Suomen sanojen alkuperä. Etymologinen sanakirja. 1: A-K, 1992; 2: L-P, 1995; 3: R-Ö, 2000. Helsinki: Suomalaisen Kirjallisuuden Seura.

V a r e, Silvi 2012. Eesti keele sõnapered. Kd 1-2. Tallinn: Eesti Keele Sihtasutus. WT [1686] 2001 = Wastne Testament 1686. Tallinn: Eesti Keele Sihtasutus. 
W i e d e m a n n, Ferdinand Johann [1893] 1973. Estnisch-deutsches Wörterbuch.

Vierter unverändeter Druck nach der von Jakob Hurt redigierten Auflage. Tallinn: Valgus.

W i n k l er, Eberhard, P a j u s a l u Karl 2009. Salis-livisches Wörterbuch. Tallinn:

Teaduste Akadeemia Kirjastus.

\section{Random Notes on a Long-Awaited Etymological Dictionary}

Keywords: etymological dictionary, structure of vocabulary, questionable etymologies

The Estonian etymological dictionary by Iris Metsmägi (chief-editor), Meeli Sedrik and Sven-Erik Soosaar is welcomed as it fills a gap in the system of Estonian dictionaries. Most of the review is concentrated on technical problems of the presentation of etymologies, as well as on spelling problems and on the interrelations of primary and contemporary meanings. The reviewers recommend that, in future, a more exact spelling should be used and references to the authors of certain etymologies be added.

Mati Hint (b. 1937), Professor Emeritus of Tallinn University

Raimo Anttila (b. 1935), Professor Emeritus of UCLA 